\title{
Komik Digital Warak Ngendog Untuk Memperkenalkan Nilai Kearifan Lokal Kepada Anak Di Kota Semarang
}

\author{
Abi Senoprabowo ${ }^{1}$, Khamadi², Yumna Anindya Septiani ${ }^{3}$ \\ ${ }^{1,2,3}$ Program Studi Desain Komunikasi Visual, Universitas Dian Nuswantoro, Jl. Imam Bonjol No.207, \\ Pendrikan Kidul, Kec. Semarang Tengah, Kota Semarang, Jawa Tengah, Indonesia 50131
}

Correspondence: Khamadi (khamadi@dsn.dinus.ac.id)

Received: 140621 - Revised: 170821 - Accepted: 170821 - Published: 100921

\begin{abstract}
Abstrak. Upaya pelestarian budaya Warak Ngendog telah banyak dilakukan seperti identifikasi dan dokumentasi budaya tradisi lewat penulisan, foto dan video. Upaya tersebut hanya sampai kepada mereka yang benar-benar tertarik dengan budaya tradisi saja. Padahal saat ini budaya tradisi agar tetap lestari harus mampu mengikuti perkembangan zaman. Untuk dapat bertahan dengan baik, maka budaya Warak Ngendog harus bertransformasi menjadi lebih modern. Sehingga dengan memanfaatkan perkembangan IPTEK saat ini, Warak Ngendog dirasa dapat diadaptasikan ke dalam komik digital sehingga anak dapat memahami nilai kearifan lokal yang terkandung dalam Warak Ngendog. Penelitian ini menggunakan metode deskriptif kualitatif dengan pendekatan analisis data melalui nilai-nilai kearifan lokal dan pendekatan perancangan komik digital. Data yang dianalisis menjadi dasar perancangan komik berupa desain karakter komik dan unsur storytelling. Sebagai hasilnya, karakter komik berupa desain karakter Warak Ngendog dengan mengadaptasikan nilai estetika, religius, dan sosial dari nilai kearifan lokal yang dimilikinya. Komik Warak Ngendog mengedepankan nilai sosial dan religius dalam penceritaan dan dikembangkan dalam perancangan di media digital yang interaktif dan mudah diakses oleh anak saat ini.
\end{abstract}

Kata kunci: kearifan lokal, komik digital, Warak Ngendog

Citation Format: Senoprabowo, A., Khamadi, \& Septiani, Y.A. (2020). Komik Digital Warak Ngendog Untuk Memperkenalkan Nilai Kearifan Lokal Kepada Anak Di Kota Semarang. Prosiding Seminar Nasional Abdimas Ma Chung (SENAM), 2020, 01-13. 


\section{PENDAHULUAN}

Warak Ngendog merupakan binatang imajiner yang berwujud gabungan beberapa binatang sebagai simbol persatuan dari berbagai golongan etnis di Semarang yaitu Cina, Arab dan Jawa. Binatang ini memiliki nilai spiritual dan nilai filosofis yang diwujudkan dalam bentuk dan cara memainkanya. Bentuk Warak Ngendog (Senoprabowo, 2013) adalah kepalanya menyerupai kepala naga (Cina), tubuhnya layaknya buraq (Arab), dan empat kakinya menyerupai kaki kambing (Jawa). Binatang ini muncul pada saat acara Dugderan yaitu sebuah acara ritual menyambut awal Ramadhan (Triyanto, Rokhmat, \& Triyanto, 2013).

Dahulu di setiap acara Dugderan, Warak Ngendog menjadi mainan yang wajib dimiliki oleh anak-anak Semarang, namun sekarang mulai ditinggalkan. Anak-anak sekarang lebih menggemari karakter-karakter dari luar negeri semacam Marsha \& The Bear, Shiva, Doraemon, dan Upin ipin yang tercermin pada jenis-jenis mainan yang dijual pada saat Dugderan. Akibat yang ditimbulkan mainan Warak Ngendog mulai disisihkan dari dagangan karena kurang laku dan dicari pengunjung Dugderan (Wicaksono \& Royanto, 2017).

Dengan adanya fenomena ini, maka perlu adanya suatu revitalisasi karakter Warak Ngendog sebagai binatang imajiner khas Kota Semarang agar bisa diterima masyarakat semarang, khususnya anak-anak. Proses revitalisasi diharapkan membuat karakter Warak Ngendog menjadi kuat dan impresif. Pendekatan yang digunakan adalah teori kognitif psikologi perkembangan, Piaget dalam Santrock (Santrock, 2003) berpendapat bahwa anak-anak menyesuaikan pemikiran mereka untuk menguasai gagasan-gagasan baru, karena informasi tambahan akan menambah pemahaman mereka terhadap dunia baru. Adanya interaksi antara anak-anak dengan Warak Ngendog akan membuat psikologi kognitif anak terhadap Warak Ngendog berkembang.

Masyarakat Indonesia sering kali terjebak dalam persoalan-persoalan kearifan lokal yang tersisihkan oleh modernitas. Masyarakat sedang dihadapkan pada persoalan sederhana, yaitu memilih menjadi tradisional atau menjadi modern (Hardiman, 2003). Upaya pelestarian tidak sebatas menjaga budaya tradisi tetap ada, tetapi juga dapat berkembang sesuai dengan perkembangan jaman (Sujarno, 2011). Oleh karena itu, transformasi Warak Ngendog ini akan merepresentasikan budaya Cina, Jawa dan Arab sebagai nilai akar dari budaya ini. Warak Ngendog ini juga akan tetap mempunyai nilai spiritual dan filosofi yang ada sebelumnya. Salah satu contoh nilainya adalah anak-anak 
selalu diberi pesan pada orang tua mereka bahwa apabila mereka dapat menjaga mainan Warak Ngendog tersebut melalui berpuasa di bulan Ramadhan, maka mereka akan mendapatkan telur Warak Ngendog yang disimbolkan sebagai kemuliaan. Nilai-nilai ini ditransformasikan ke dalam bentuk modern sehingga tetap lestari di era modern. Salah satu media yang dapat digunakan yaitu Komik. Secara umum, komik berperan untuk menyampaikan informasi dan mencapai tanggapan estetis dari pembacanya.

Komik merupakan media komunikasi visual yang unik karena menggabungkan teks dan gambar dalam bentuk yang kreatif serta mempunyai kekuatan untuk menyampaikan informasi secara popular dan mudah dimengerti (Wahyuningsih, 2012). Komik sendiri merupakan media penyampaian pesan dengan menggunakan media cetak dan digital. Pemanfaatan komik untuk media pembelajaran mempunyai sifat sederhana, jelas, dan mudah untuk dipahami oleh anak (Novianti \& Syaichudin, 2010). Sehingga komik dapat dikatakan dapat menjadi media yang memiliki nilai edukatif. Selain itu, media komik dalam proses belajar mengajar juga dapat menciptakan minat peserta didik terhadap materi yang diajarkan sehingga proses belajar mengajar menjadi efektif. Komik dinilai juga dapat mengembangkan kreativitas siswa. Sehingga dengan memanfaatkan perkembangan IPTEK saat ini, maka komik digital Warak Ngendog dirasa dapat menjadi jawaban akan pentingnya penanaman nilai kearifan lokal yang ada pada mainan Warak Ngendog kepada anak di era modern seperti sekarang ini.

\section{METODE PELAKSANAAN}

Penelitian ini menggunakan metode deskriptif kualitatif yaitu suatu prosedur penelitian yang menggunakan data deskriptif berupa kata-kata tertulis atau lisan dari orang-orang dan pelaku yang dapat diamati (Sugiyono, 2012). Melalui metode tersebut akan dipaparkan fakta, keadaan, dan fenomena budaya Warak Ngendog saat ini. Sumber data pada penelitian ini dapat dibagi menjadi dua jenis sumber data yaitu sumber data primer dan sumber data sekunder. Sumber data primer berasal dari wawancara secara langsung ke tim peneliti sejarah Warag Ngendog, Bapak Fikri Budiman dan pengrajin serta penjual Warag Ngendog. Selama observasi dan wawancara dilakukan pengumpulan sumber data berupa dokumentasi secara foto dan video dari kegiatan yang dilakukan. Selanjutnya sumber data sekunder didapatkan dari penelusuran data dari sumber literatur berupa buku, jurnal, gambar dan sebagainya terkait mainan Warak Ngendog. 
Selanjutnya juga dilakukan analisis data secara deskriptif. Kemudian hasil analisis menjadi dasar perancangan komik digital dengan pendekatan perancangan desain karakter dan storytelling komik dan pendekatan digital storytelling.

\section{HASIL DAN PEMBAHASAN}

\section{Nilai Kearifan Lokal dalam Warak Ngendog}

Azan (2013: 32) menyebutkan kearifan lokal dapat dikategorikan ke dalam dua aspek, yaitu aspek kearifan lokal yang berwujud nyata (tangiable) dan yang tidak berwujud (intangiable). Secara fisik, Warak Ngendog merupakan kearifan lokal yang berwujud nyata (tangible). Namun, di dalam Warak Ngendog terkandung nilai-nilai yang menjadi filosofi dari bentuk fisik, kegunaan, dan sejarah keberadaannya. Seperti yang disampaikan Taylor dan de Leo dalam Chaipar (2013) menjelaskan bahwa kearifan lokal adalah tatanan hidup yang diwarisi dari satu generasi ke generasi lain dalam bentuk agama, budaya, atau adat istiadat yang umum dalam sistem sosial masyarakat. Sehingga Warak Ngendog sebagai sebuah produk budaya tradisi mengandung nilai-nilai yang dipegang dan disepakati bersama oleh masyarakat sebagai identitas lokal masyarakat yaitu masyarakat kota Semarang. Hal ini nampak dari Warak Ngendog yang menghiasi wajah Semarang sebagai maskot kota Semarang yang secara visual dapat ditemui keberadaannya dalam patung kota, mainan khas, hingga maskot dan identitas bagi kegiatan yang diselenggarakan oleh masyarakat dan Pemerintah kota Semarang.

Nilai-nilai kearifan lokal menurut teori Alport (dalam Syarbaini, 2014:44) meliputi nilai teori, nilai ekonomi, nilai religius, nilai estetika, nilai sosial, dan nilai politik.

1) Nilai religius. Keberadaan Warak Ngendog sebagai penanda awal bulan Ramadhan sarat dengan nilai religius terkait hubungan manusia dengan Tuhan dan hubungan manusai dengan sesama manusia lainnya. Triyanto dkk (2013) menjelaskan secara simbolik dari bentuk kepala dan leher yang bewarna merah merupakan hewan yang rakus dan beringas sebagai simbol nafsu manusia oleh karena itu perlu dikendalikan dengan simbol bulu khas warak yang berupa kebalik (pithik walik). Secara ekspresi raut muka yang ditampilkan membentuk karakter hewan yang berangas, menakutkan, dan rakus. Hal ini dilihat dari sisi religius yang ingin disampaikan adalah manusia supaya tidak tamak seperti binatang dalam berpuasa.

2) Nilai sosial berarti berorientasi kepada hubungan antar manusia dan menekankan pada segi-segi kemanusiaan yang luhur. Warak Ngendog dengan bentuk fisiknya yaitu 
bentuk kepala, badan, hingga warna yang merepresentasikan sebagai simbol akulturasi budaya Cina, Jawa, dan Arab dengan masing-masing memberikan sumbangsih pada bentuk fisik tersebut. Akulturasi budaya ini tercermin dari hubungan yang baik secara sosial, saling menghargai dan dapat hidup berdampingan antar etnis yang ada di Semarang. Warak Ngendog menjadi simbol persatuan dan tidak melihat orang lain berdasarkan kedudukan, semuanya saling mendukung menjadi satu kesatuan dalam upaya mencapai kebaikan hidup bersama.

3) Nilai estetika. Warak Ngendog secara visual dan bentuk serta proses pembuatannya memiliki keunikan yang spesifik. Hal ini terlihat dari keberadaanya yang hanya ada di Semarang dan menjadi identitas kota Semarang. Bentuk yang detail dan spesifik meliputi bagian Warak Ngendog seperti kepala kambing Jawa, leher unta Arab, dan badan mirip kilin Cina. Selain itu paduan warna merah khas Cina, kuning keemasan khas Jawa, dan hijau khas Islam Arab, menunjukkan tingginya nilai estetika yang dimiliki Warak Ngendog. Kemudian telur warna putih yang kini jarang ditampilkan bersama sosok Warak.

4) Nilai ekonomi tampak pada tradisi dugderan yang menjadikan Warak Ngendog sebagai maskotnya. Pada tradisi Dugderan dimana terdapat kegiatan pasar malam menjadi penggerak ekonomi bagi masyarakat dengan menjual mainan khas Warak Ngendog. Sehingga muncullah produsen pengrajin Warak Ngendog baik dalam bentuk mainan ataupun properti yang digunakan untuk arak-arakan saat prosesi acara dugderan. Meskipun permintaan Warak Ngendog ini bisa dikatakan musiman yaitu menjelang bulan Ramadhan.

5) Nilai politik juga tampak jelas pada interaksi antara Pemerintah, masyarakat, dan ulama pada prosesi Dugderan yaitu Warak Ngendog menjadi simbol kesatuan dan integrasi budaya masyarakat Semarang yang multikultur. Secara tidak langsung Warak Ngendog diakui sebagai wujud pemersatu masyarakat yang multietnis serta bersatunya pemerintah, masyarakat, dan ulama. Sebagai contoh dalam kegiatan pemerintahan, Warak Ngendog sering muncul menjadi maskot visual dalam menyampaikan programprogram pemerintah kepada masyarakat. Hal ini menunjukkan bahwa sosok Warak Ngendog mudah diterima dan diakui menjadi milik bersama. 


\section{Karakter Warak Ngendog dalam Pendekatan Perancangan Komik}

Tidak bisa dipungkiri bahwa cerita yang baik dalam komik juga sangat dipengaruhi dengan penokohan karakter yang mampu membawakan cerita dengan baik. Sehingga karakter yang menarik akan menjadi daya tarik utama secara visual. McCloud (2006, p. 63) menjelaskan bahwa terdapat tiga kualitas yang perlu ada pada karakter; inner life, visual distinction, dan expressive traits.

\section{1) Inner Life}

Tahap pertama dalam membuat suatu karakter berawal dari aspek internalnya, yaitu sifat, keinginan, masa lalu, dan cara pandang karakter. Warak Ngendog pada dasarnya tidak memiliki cerita bawaan seperti kisah atau legenda karena pada dasarnya Warak Ngendog sebagai sebuah simbol. Namun dilihat dari nilai religius yang dikandung yaitu perwujudan sikap yakin dan sabar dengan tidak tamak dan rakus serta berbuat kebaikan dalam menjalankan puasa sehingga pada akhirnya mendapatkan keberkahan dan pahala yang disimbolkan dengan telur atau endog. Sehingga secara sederhana melihat kata Warak Ngendog yaitu adanya karakter Warak yang memiliki potensi ketamakan dan rakus seperti sifat negatif manusia tetapi mampu menahan diri waro'a) sehingga dia berhasil mendapatkan endog karena kemampuannya tadi. Sehingga secara konsep kata kunci warak ngendog dapat diberikan sifat "kuat" "bijak", dan "penyabar". Kuat dapat definisikan memiliki keinginan atau karakter kuat atau juga memiliki fisik kuat dan besar. Bijak representasi dari kebaikan, amal sholeh, dan bijaksana dalam menempatkan diri dan melihat segala sesuatunya. Sedangkan penyabar representasi sifat sabar mencapai keberkahan pahala. Namun, dalam perancangan karakter yang menarik, karakter juga diberikan sifat yang bersifat menjadi kekurangan misal sembrono, mudah percaya, mudah takjub, dan sebagainya. Pada karakter Warak Ngendog sifat yang bisa diberikan adalah "pelupa" untuk mengimbangi sifat kuatnya. Sifat lupa ini juga diambil dari konsep puasa yang tidak batal karena lupa makan dan minum.

\section{2) Visual Distinction}

Aspek internal suatu karakter yang beragam tentunya dapat menghasilkan penampilan visual suatu karakter yang bervariasi pula. Bagi McCloud (2006, p. 70), variasi dan ciri khas karakter adalah aspek yang penting karena dapat membantu pembaca untuk membedakan antar karakter. Di dalam pengembangan cerita di komik dengan tema fiksi nantinya akan muncul karakter-karakter lain sebagai pendukung. 
Tetapi fokus pada perancangan ini adalah karakter Warak Ngendog. Berdasarkan nilai estetika, secara visual Warak Ngendog memiliki keunikan bentuk dan warna yang bisa menjadi unsur visual distinction. Bentuk karakter dengan perpaduan kepala, leher, badan yang memiliki paduan nilai multikultural menjadi dasar pengembangan karakter yang sesuai dengan inner life yang dimiliki. Secara sederhana karakter bisa ditampilkan sesuai referensi bentuk Warak Ngendog pada aslinya, tetapi dalam kebutuhan penceritaan dan membuat karakter menarik, Warak Ngendog dapat dipersonifikasikan layaknya manusia dengan tetap menekankan keunikan dan filosofi bentuk Warak Ngendog.

3) Expressive Traits

Setiap karakter memiliki keunikan dalam cara berekspresi, dari cara mereka berbicara, sampai keunikan dalam bertingkah laku. Untuk mengenal karakter lebih dalam, McCloud menyarankan agar karakter memiliki dua sampai dengan tiga key expressions atau pose (McCloud, 2006, p. 76-77). Key expressions yang dimaksud adalah beberapa ekspresi penting yang memperkuat keunikan karakter, seperti pada contohnya, pada saat sedang berpikir, karakter yang serius pastinya menunjukkan ekspresi dan pose yang berbeda dibandingkan karakter yang humoris.

Dalam perancangan karakter Warak Ngendog keunikan ini dapat diwujudkan dari sifat yang diberikan yaitu pose atau ekspresi saat lupa, saat menunjukkan kekuatannya, dan saat bijak seperti memberikan petuah.

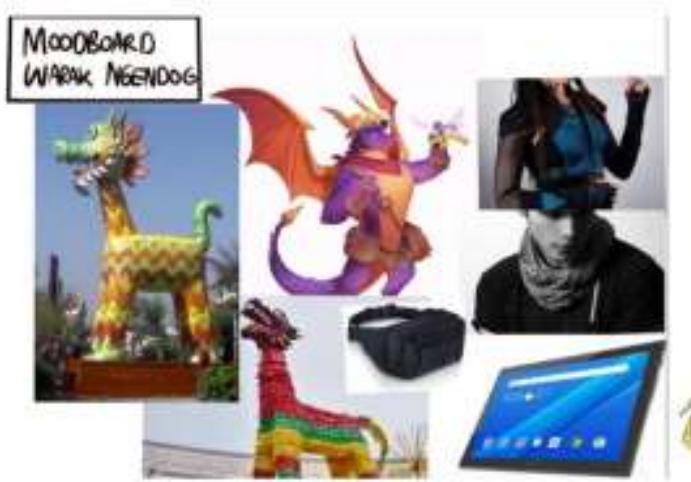

a

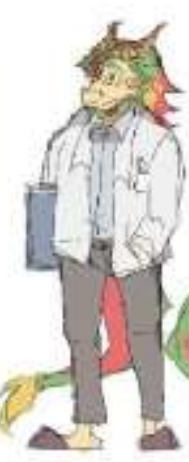

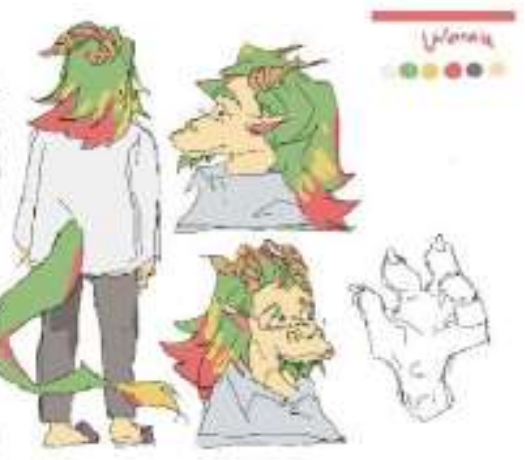

b

Gambar 1. (a) Moodboard dan (b) desain karakter Warak Ngendog 
Untuk data dalam bentuk tabel, penyajiannya menggunakan contoh seperti dalam

Tabel 1. Terlihat bahwa hanya dibutuhkan garis-garis horisontal pada pembuatan tabel. Pergunakanlah style yang sudah disediakan untuk tabel maupun gambar dalam template ini.

\section{Perancangan Komik Warak Ngendog berbasis Digital Storytelling}

Digital Storytelling (selanjutnya disebut DST) merupakan pengembangan dari storytelling yakni teknik bercerita secara digital. Interaksi yang terjadi dalam DST yaitu: collaborate, communicate, dan connect. Sedangkan tools yang menunjang kegiatan ini menurut Tolisano (2009) tersusun dari: choose/create media, storyline, serta project.
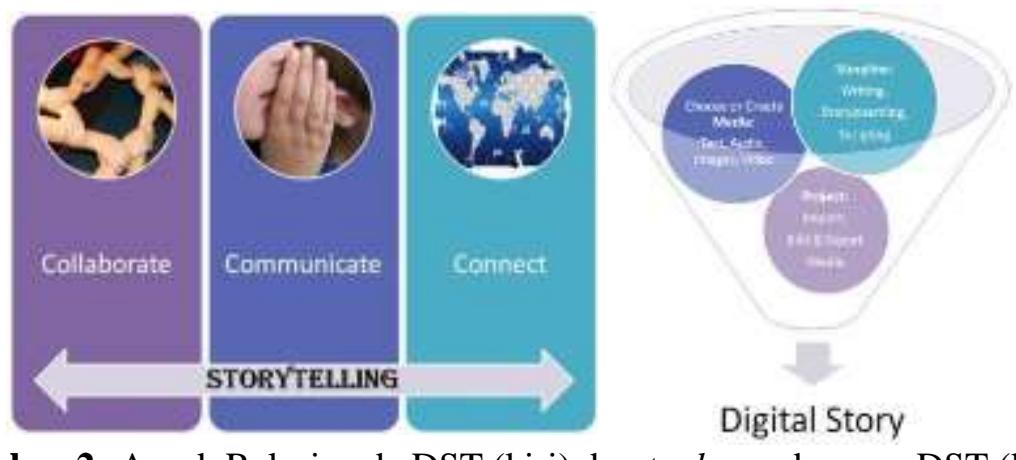

Gambar 2. Aspek Relasi pada DST (kiri) dan tools pembangun DST (kanan)

Selanjutnya dari bagan di atas dapat dijelaskan terkait perancangan komik digital Warak Ngendog dengan aspek relasi pada proses storytelling berupa:

1) Collaborate yakni kolaborasi antara peneliti dengan budayawan dalam mengembangkan nilai-nilai budaya Warak Ngendog untuk disampaikan kepada sasaran yaitu remaja generasi muda saat ini.

2) Communicate yakni pesan yang ingin disampaikan terkait budaya Warak Ngendog yaitu filosofi dan nilai kearifan lokal sebagaimana yang telah dibahas pada bab sebelumnya yang diwujudkan dalam pengembangan desain karakter Warak Ngendog dan dikuatkan dengan penceritaan dalam bentuk komik digital.

3) Connect yakni cara penyampaian pesan (teknik penceritaan) kepada target sasaran generasi muda saat ini yaitu lewat media yang dekat dengan mereka. Melihat akses internet dan penggunaan gadget yang tinggi, maka pendekatan penceritaan ke generasi muda melalui aplikasi komik digital yang mudah diakses dan menarik untuk dibaca. 
Pada aspek tool lebih pada aspek teknis dalam penceritaan pesan budaya Warak Ngendog lewat media komik digital, sehingga dapat dijelaskan sebagai berikut yaitu:

1) Choose/create media. Perancangan ini berupaya membuat media baru penyampaian pesan budaya Warak Ngendog melalui komik secara digital. Namun, dalam pengembangan digitalnya masih menggunakan aplikasi yang sudah tersedia. Sesuai unsur komik, penggunaan unsur multimedia yang digunakan adalah text, image, dan audio. Text berupa balon kata dan narasi yang muncul dalam komik. Image berupa visualisasi ilustrasi dalam komik yang disesuaikan dengan pendekatan visual yang disukai oleh generasi saat ini. Audio berupa suara musik dan efek suara yang digunakan untuk meningkatkan pengalaman pengguna dalam membaca komik digital.

2) Storyline. Pada perancangan ini pendekatan cerita yang disampaikan didasarkan pada nilai-nilai kearifan lokal yang terkandung dalam Warak Ngendog. Pada unsur storyline terdiri dari 3 unsur yaitu writing, storyboarding, dan scripting.

a) Writing yaitu penulisan cerita dasar komik Warak Ngendog sebagai berikut:

\begin{tabular}{ll}
\hline Judul & Tetanggaku Warak \\
\hline Tema & Persahabatan, slice of life \\
\hline Logline & $\begin{array}{l}\text { Seekor kelinci yang sedang beradaptasi dengan lingkungan baru tetapi } \\
\text { memiliki tetangga Warak Ngendog yang terlalu perhatian. }\end{array}$ \\
\hline Pesan/Amanat & Jangan melihat orang dari tampilan luarnya saja \\
\hline Alur & Maju \\
\hline Cerita Dasar & \\
\hline
\end{tabular}

\section{Perkenalan}

Mai, pindah rumah ke Semarang karena dia akan kuliah di sana. Tidak disadari oleh Mai, ternyata dia mempunyai tetangga yang unik yang bernama Warak Ngendog. Mai adalah seorang kelinci ras langka yang pendiam, selalu dingin pada hewan - hewan, salah satunya adalah Rakun yang selalu mengincar Mai. Mai tidak suka diajak bicara jika obrolannya hanya basa-basi. Sedangkan Warak Ngendog adalah hewan yang memiliki campuran dari naga, unta, dan lain-lain. Dia tetangga yang sangat baik, ramah, selalu menjawab sapaan orang, sehingga warga Semarang menyukai karakter Warak Ngendog. Kemudian Mai bertemu Rakun seorang dosen yang sangat baik pada Mai. Namun, ternyata Rakun mempunyai niat buruk terhadap Mai.

\section{Konflik}

Terjadi kebakaran di pasar dekat rumah yang di sebabkan oleh Rakun, sehingga Warak menjadi sibuk menyelamatkan korban disana. Lalu Mai yang sedang di rumah, dan diam diam diculik oleh Rakun.

\section{Klimaks}

Ketika Warak sudah selesai menyelamatkan orang- orang, ia mempunyai firasat buruk tentang Mai lalu langsung mencari Mai di rumahnya. Ternyata, Mai sudah tidak ada 
dirumah dan terlihat sekeranjang wortel yang berserakan di lantai. Dan ternyata benar Mai diracuni oleh Rakun dan diculik.

\section{Peleraian}

Warak pun mencari Mai hingga akhirnya Warak dan polisi sampai di suatu tempat. Dan menemukan Mai yang sedang diculik oleh Rakun. Warak yang marah kemudian menyerang Rakun dan menangkap Rakun yang berusaha melarikan diri. Kemudian Warak menyelamatkan Mai.

\section{Penyelesaian}

Mai melihat Warak Ngendhog sebagai karakter yang baik. Hubungan Mai dan Warak mulai membaik. Mai ingin menjadi seperti Warak dan mencoba berusaha menjadi kelinci yang baik dan disukai hewan-hewan.

b) Storyboarding dan scripting pada cerita ini ditunjukkan pada perancangan paneling komik sebagai berikut.
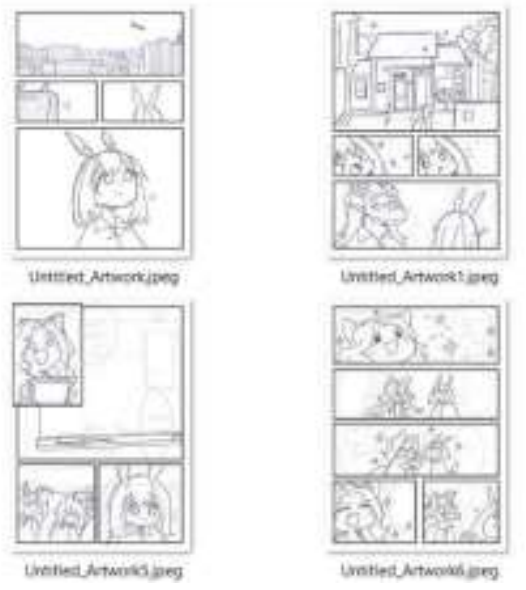
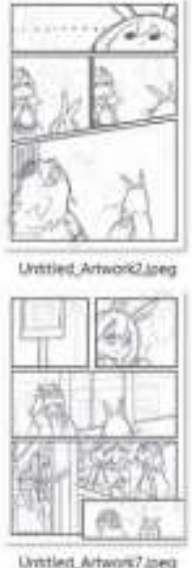
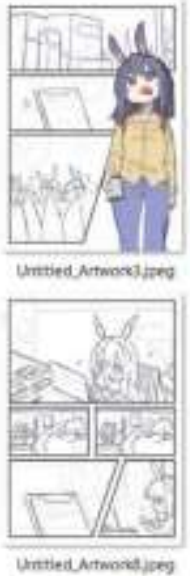
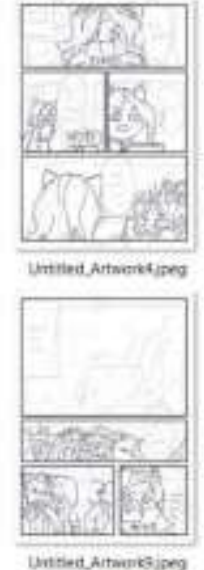

Gambar 3. Storyboard paneling komik

3) Project. Tahap ini meliputi import, edit dan export media. Namun, dalam pembuatan komik digital ini dimulai dengan pewarnaan dan pengisian text pada paneling seperti berikut ini. 


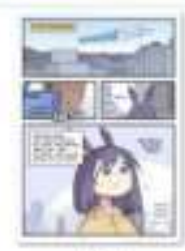

$4 \times 9$

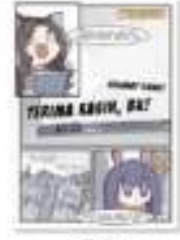

Sipg
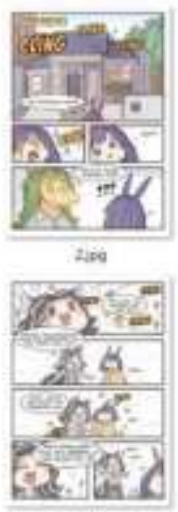

Tion
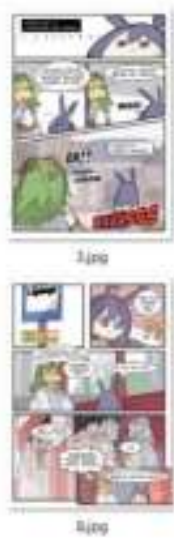
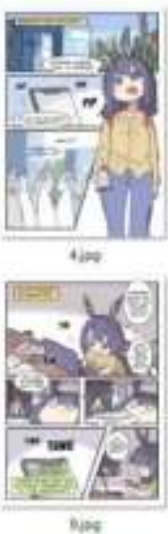

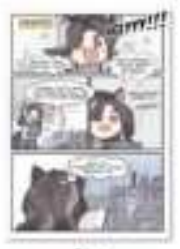

Lat

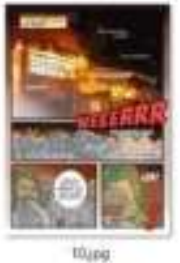

Gambar 4. Pewarnaan dan pengisian balon kata komik.

Selanjutnya kumpulan panel di atas disatukan dalam bentuk PDF untuk menjadi sebuah buku komik. Konsep digital storytelling, komik tersebut kemudian di-import ke aplikasi digital untuk bisa di-export menjadi komik digital yang interaktif sederhana yaitu menggunakan aplikasi anyflip.

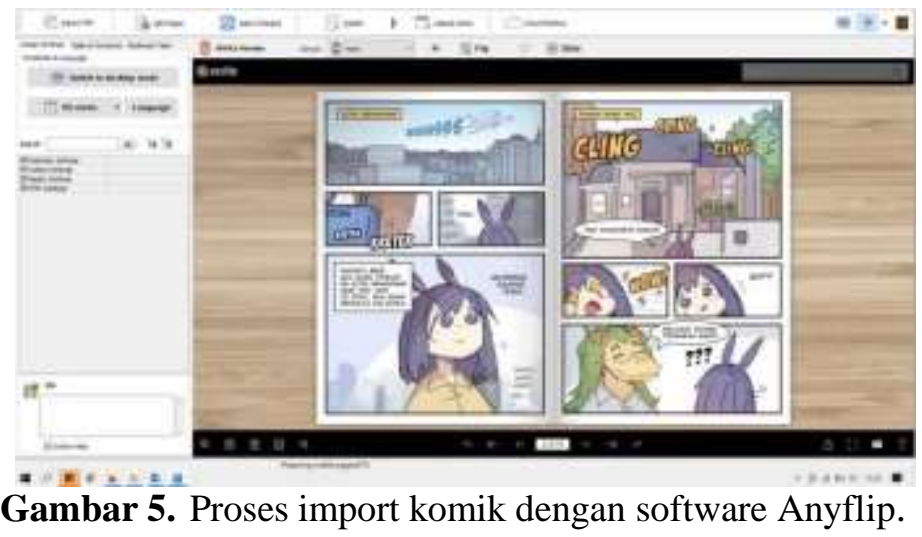

Selanjutnya komik akan disetting sesuai dengan kebutuhan baik dalam tampilan desktop maupun tampilan dalam mobile phone. Kemudian komik di export dalam media desktop maupun mobile. Berikut adalah contoh tampilan komik digital Warak Ngendog dalam tampilan desktop. 


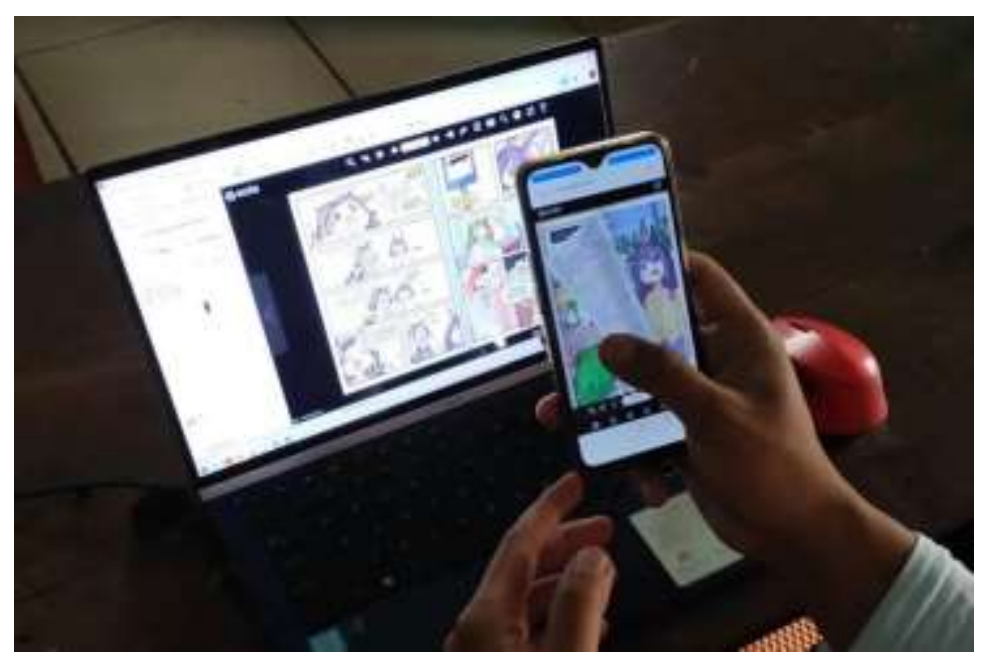

Gambar 6. Display komik dalam tampilan mobile phone.

\section{KESIMPULAN}

Pengembangan Warak Ngendog dalam sebuah komik digital perlu memperhatikan nilai-nilai kearifan lokal yang dimiliki. Namun, tidak semua nilai harus dipaksa untuk direpresentasikan pada perancangan komik tersebut minimal dengan perancangan desain karakter komik yang mewakili nilai estetika yang dimiliki Warak Ngendog. Hal ini dikarenakan dengan jenis dan media yang dipilih. Walaupun tidak menutup kemungkinan desain karakter yang dibuat dapat dikembangkan sesuai dengan jenis media lain yang akan dibuat. Pada penelitian ini dapat disimpulkan bahwa daya tarik karakter Warak Ngendog untuk kebutuhan media komik sangat memperhatikan nilai estetika, nilai sosial, dan nilai religius yang dimiliki oleh Warak Ngendog. Nilai teori, ekonomi, dan politik kurang dikembangkan dalam perancangan ini mengingat tujuan penelitian sebagai edukasi masyarakat tentang pengenalan nilai dan filosofi yang dimiliki Warak Ngendog, bukan sebagai alat untuk memenuhi kebutuhan ekonomi ataupun politik.

Akhirnya dengan pengembangan yang terstruktur dengan memperhatikan nilai budaya Warak Ngendog dan aspek budaya dalam komik yaitu storytelling dan desain karakter dapat mengawinkan nilai-nilai budaya yang dianggap tradisional dengan budaya modern yang disukai generasi saat ini. Selanjutnya perancangan komik digital dapat meningkatkan pendekatan aspek storytelling dalam pembuatan naskah komik yang dapat menghadirkan pesan-pesan sosial dan religi yang dimiliki oleh Warak Ngendog melalui desain karakter komik yang telah dibuat. 


\section{UCAPAN TERIMA KASIH}

Terima kasih untuk program penelitian Internal Universitas Dian Nuswantoro, Semarang atas dukungan biaya penelitian yang diberikan, dan untuk narasumber yang membagi informasi bagi penelitian ini.

\section{DAFTAR PUSTAKA}

Azan, Riski Rian. 2013. Upaya Penguatan Karakter Melalui Internalisasi Nilai- Nilai Kearifan Lokal pada Pembelajaran Sejarah di SMA Negeri 1 Kendal Tahun Ajaran 2012/2013. Skripsi. Universitas Negeri Semarang.

Chaipar W, et al. 2013. Local Wisdom in the Environmental Management of a Community: Analysis of Local Knowledge in Tha Pong Village, Thai- land. Dalam Journal of Sustainable Development. Vol. 6 No. 2, hal 17-22

Hardiman, F. B. (2003). Melampaui Positivisme dan Modernitas: Diskursus Filosofis Tentang Metode Ilmiah dan Problem Modernitas. Yogyakarta: Kanisius.

Novianti, R. D., \& Syaichudin, M. (2010). Pengembangan Media Komik Pembelajaran Matematika Untuk Meningkatkan Pemahaman Bentuk Soal Cerita Bab Pecahan Pada Siswa Kelas V SDN Ngembung. Jurnal Teknologi Pendidikan, 10(1), 74-85.

Santrock, J. W. (2003). Adolescence Perkembangan Remaja (edisi 6). Jakarta: Erlangga. Senoprabowo, A. (2013). Perancangan Game Warak Ngendog untuk Menanamkan NilaiNilai Spiritual kepada Anak Sekolah Dasar (Tesis). Institut Teknologi Bandung, Bandung.

Senoprabowo, A., \& Khamadi, K. (2018). Model Transformasi Mainan Warak Ngendog sebagai Upaya Pelestarian Budaya Mainan Tradisional Kota Semarang. ANDHARUPA: Jurnal Desain Komunikasi Visual \& Multimedia, 4(02), 221-238.

Sugiyono, S. (2012). Memahami Penelitian Kualitatif. Bandung: Alfa Beta.

Sujarno, S. (2011). Permainan Tradisional sebagai Jembatan Pembentukan Karakter Bangsa. Jantra, 6(12), 116-123.

Tolisano, S.R. (2009). How to Guide Digital Storytelling Tools for Educators. Creative Commons

Triyanto, T., Rokhmat, N., \& Triyanto, M. (2013). Warak Ngendog: Simbol Akulturasi Budaya pada Karya Seni Rupa. Komunitas: International Journal of Indonesian Society Culture, 5(2).

Wahyuningsih, A. N. (2012). Pengembangan Media Komik Bergambar Materi Sistem Saraf Untuk Pembelajaran Yang Menggunakan Strategi PQ4R. Journal of Innovative Science Education, 1(1), 19-27.

Wicaksono, B. A., \& Royanto, D. (2017). Makhluk Berkaki Empat Nyaris Punah di Tradisi Dugderan. VIVA.co.id.

(C) 2021 by authors. Content on this article is licensed under a Creative Commons Attribution 4.0 International license. (http://creativecommons.org/licenses/by/4.0/). 